УДК 336.77:338.437

JEL classification: G21 O16 Q14

Лупенко Ю.О.

доктор економ .наук, професор, ORCID ID: 0000-0001-6846-0300

академік Національної академії аграрних наук,

Національний науковий центр «Інститут аграрної економіки»

Андрос C.B. доктор економ. наук, доцент, пров. наук. співробітник, ORCID ID :: 0000-0001-5561-901X

Національний науковий цеентр «Інститут аграрної економіки»

\title{
БАНКІВСЬКЕ КРЕДИТУВАННЯ АГРАРНОГО СЕКТОРУ ЕКОНОМІКИ
}

\section{BANK LENDING TO THE AGRICULTURAL ECONOMY SECTOR}

Проаналізована ситуація на ринку банківського кредитування сільськогосподарських підприємств. Виявлено основні фактори попиту на кредитні ресурси з боку сільськогосподарських підприємств. Показані особливості кредитування підприємств малого i середнього агробізнесу. Виявлено вплив банківського кредиту на розвиток агросектору в Україні. Піднімаються актуальні проблеми недостатності фінансових ресурсів для розвитку підприємств агропромислового комплексу, ріменням яких можуть стати програми пільгового кредитування, надання позик на прийнятних умовах сільським товаровиробникам. Встановлені ключові причини низької ефективності чинного механізму кредитування банками агропромислового сектору. Дана очінка діючим механізмам фінансування сільськогосподарських товаровиробників. Виявлено ключові недоліки в системі фінансування підприємств агропромислового комплексу. Розглянуті основні перешкоди кредитування фінансово-кредитними установами сільського господарства Украйни $i$ запропоновані варіанти їх усунення. Доказана суперечливість системи кредитування підприємств агропромислового комплексу Украӥни. Розкриті прогалини в законодавчо-нормативному середовищі щуодо фінансування сільськогосподарських підприємств. Доведено, що розвиток кредитування відкриває широкі можливості для розвитку підприємств аграрного сектора. Доказано, шо ефективно налагоджена система кредитування дозволяє банкам розглядати надання позик під заставу земель сільськогосподарського призначення як один з найбільш надійних $i$ безпечних способів інвестування коштів у сільське господарство. Розглянута практика найбільш ефективно використовуваних фінансових інструментів та програм підтримки сільськогосподарських підприємств фінансово-кредитними установами Украӥни. Встановлені фактори впливу від найбільш важливого до найменш значущого на прийняття рішення про кредитування сільгоспвиробника і продемонстровано орієнтовний процент значущості кожного, виходячи з банківської практики. Встановлені проблеми, щуо стають основними перепонами до отримання позичальником позики $i$ запропоновані шляхи їх вирішення. Сформульовані ключові елементи фінансово-аграрної експертизи, яку проводить персонал банку після отримання заявки на видачу позики.

Ключові слова: аграрії, агробізнес, банк, інструменти, кредитування, продукти.

The present situation on the market of bank crediting of agriculture is analyzed. The main factors of demand for credit resources by agricultural enterprises are revealed. The features of lending to small and medium-sized agribusiness enterprises are shown. The influence of bank credit 
on the development of agro-sector in Ukraine was revealed. The actual problems of insufficient financial resources for the development of agro-industrial enterprises are rising, the decisions of which may include preferential lending programs, loans for eligible agricultural producers. The key reasons for the low efficiency of the current mechanism of lending to the banks of the agro-industrial sector are identified. The evaluation of the existing mechanisms for the financing of agricultural producers is given. The key disadvantages in the system of financing the enterprises of the agroindustrial complex are revealed. The main obstacles to lending to financial and credit institutions of agriculture of Ukraine are considered and suggested variants of their elimination. Conflict of the credit system of the enterprises of agroindustrial complex of Ukraine is proved. The gaps in the legislative and regulatory environment regarding the financing of agricultural enterprises have been revealed. It is proved that the development of lending opens up wide opportunities for the development of enterprises in the agrarian sector. It is proved that a well-established system of lending allows banks to consider granting loans secured by agricultural land as one of the most reliable and safe means of investing in agriculture. The practice of most effectively used financial instruments and programs of support of agricultural enterprises by financial and credit institutions of Ukraine is considered. The established factors of influence from the most important to the least significant decision-making on lending to the farmer and demonstrated the indicative percentage of the significance of each, based on banking practice. Established problems that become the main obstacles to obtaining a borrower and proposed ways to solve them. The key elements of the financial and agricultural expertise, which are conducted by the Bank's employees after the receipt of an application for a loan, are formulated.

Keywords: agrarians, agribusiness, bank, tools, lending, products.

Вступ. Основою добробуту держав ЄС і США є мале підприємництво, i його підтримка стає стратегічним завданням для національної економіки i банків, які налаштовані в цій економіці ефективно працювати i, відповідно, отримувати прибутки. Проте, скільки б не говорили про перспективність українського агропромислового комплексу (АПК) і активної інтеграції нашої країни в СС, доступ вітчизняним аграріям до банківських кредитів, на відміну від їхніх європейських колег, як і раніше, залишається обмеженим.

Натомість сільське господарство - це єдина галузь, яка не постраждала від кризи 2008/09 років і наростила обсяги експорту, і при цьому в ній є значний потенціал для розвитку. В умовах імпортозаміщення сільськогосподарські кредити все більше затребувані фермерами. Але чим сильніше попит на кредити, тим обережніше поводять себе банки: агросектор - це ризикований ринок, тому більшість комерційних банків неохоче кредитують його представників. Багато банків готові надавати кредит на розвиток сільського господарства тільки своїм або перевіреним клієнтам 3 позитивною кредитною історією. Новоствореним сільгосппідприємствам отримати кредит у комерційному банку на розвиток агробізнесу практично неможливо.

Проблеми вдосконалення механізму кредитування i державного регулювання у сфері сільського господарства висвітлювалися у роботах вітчизняних вчених і практиків: Дем'яненко М.Я., Саблук П. Т., Корнійчук Г.В., Лупенко Ю.О., Непочатенко О.О., Халатур С.М. [1-5].

Незважаючи на високий рівень важливості отриманих багатьма науковцями результатів, комплексного дослідження, що висвітлює актуальні 
проблеми фінансування саме підприємств аграрного сектору економіки, доступності позик для фермерів, малих i середніх сільгоспвиробників, покращення кредитної активності комерційних банків і програм підтримки агросектору проводилося недостатньо.

Постановка завдання. Метою статті $\epsilon$ оцінка стану банківського кредитування аграрного сектору в Україні та визначення підходів щодо активізації існуючої системи кредитування агробізнесу.

Методологія дослідження спирається на системний підхід при використанні методу пізнання від абстрактного до конкретного і спеціальні методи економіко-статистичних досліджень (порівняння, угруповання, деталізації підсумкових показників, узагальнення), що допомогло забезпечити достовірність результатів дослідження i обгрунтованість висновків.

Результати дослідження. Сьогодні особливим інтересом у банків користується аграрний ринок. Проте сільгоспвиробники нарікають на дорогі банківські кредити, процентні ставки за якими іноді сягають більше ніж 20\% річних. За таких «лояльних» умов витримати жорстку конкуренцію 3 потужними закордонними компаніями на внутрішньому ринку, не говорячи вже про зовнішній ринок, і при цьому забезпечити прибутковість бізнесу українському аграрію практично неможливо.

Теоретично банки налаштовані кредитувати сільське господарство, але на практиці кредитування фермерів відбувається повільно, потреби агробізнесу у фінансових ресурсах задовольняються лише почасти. Що стосується малих $\mathrm{i}$ середніх сільгоспвиробників, вони значно обмежені в доступі до фінансування. Найбільшу перешкоду бачимо у відсутності або недостатності заставного забезпечення. Тут головними труднощами $\epsilon$ те, що фермерипозичальники не завжди можуть надати банкам адекватні застави. В Україні нині діє мораторій на продаж землі, тому вона не може бути заставним забезпеченням за кредитом. Решта видів застав банкам не так цікаві, тому кредитування залишається ризиковим і дорогим.

Зрозуміло, що фермер, якому необхідно, наприклад, 200 тис грн, скоріше за все звернеться до партнерів або в кредитну спілку, ніж у комерційний банк. Обгрунтовується це простою процедурою отримання кредиту, меншою процентною ставкою за позику, незначними додатковими витратами, у більшості випадків взагалі відсутністю кредитного забезпечення.

Ще одна проблема - закредитованість галузі. У багатьох аграрних компаніях ліміти з кредитування вже досягнуті або близькі до того. Дійсно, у багатьох сільгоспвиробників просто немає вільного від застави майна, яке могло б виступити забезпеченням для нового кредиту. Ще однією перепоною для кредитування сільгоспвиробників стає відсутність взаємодовіри між банками і аграріями. Зрозуміло, що фермер негативно відноситься до банку, який пропонує йому позику під високий процент. Аналогічно банк 3 настороженістю ставиться до фермера, який, ймовірно, не поверне не лише проценти, а і кредит загалом. Діяльність комерційних банків - бізнес, тому як i 
всі інші бізнесмени, банки хочуть бути впевнені в тому, що їх гроші обов'язково до них повернуться. Часто саме небажання позичальника йти назустріч вимогам банку є підставою для відмови у видачі кредиту.

Для банків цікавими клієнтами $\epsilon$ великі сільськогосподарські підприємства, які беруть великі суми грошей. Додатковою перешкодою в напрямі отримання фермером кредиту у банку $є$ проблеми в отриманні відшкодування частини процентної ставки за позикою зі сторони держави. Звичайно, оптимальні умови кредитування для аграріїв банк може запропонувати у випадку, якщо максимально точно оцінюе всі ризики, пов'язані з цим процесом. Прогнозування банками зміни рівня ризиків на кінець 2018 року представлено на рис. 1.

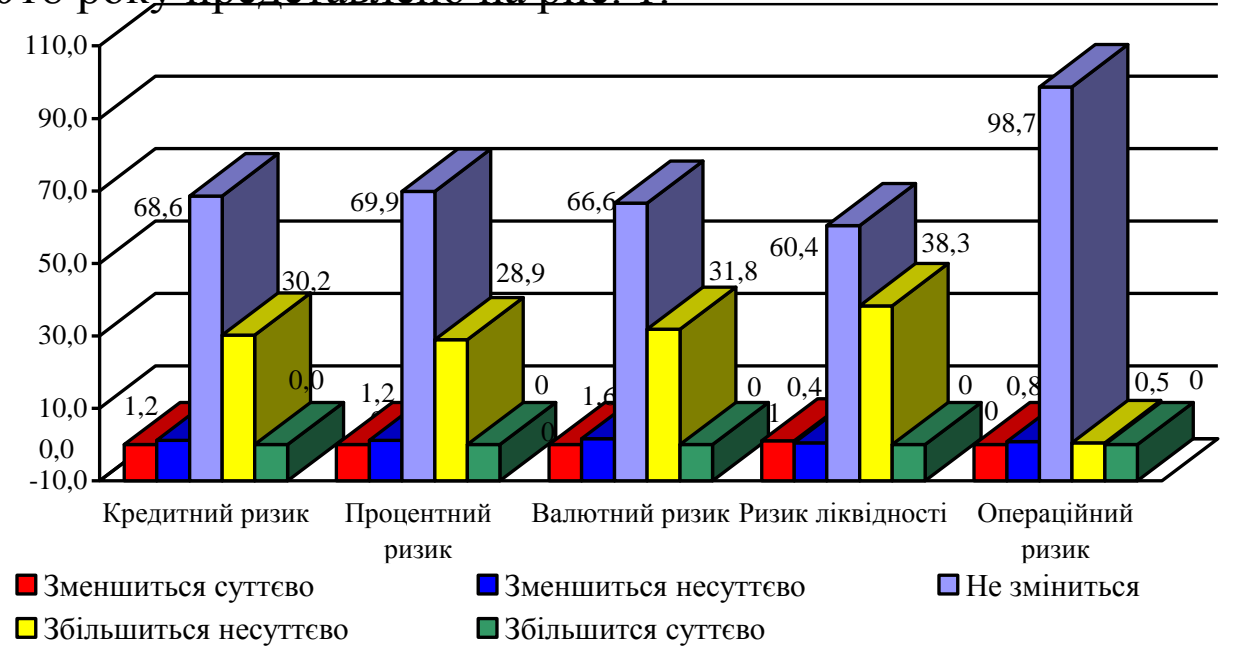

Рисунок 1 - Прогноз банків щодо зміни рівня ризиків на кінець 2018 року, \% відповідей

Джерело: складено авторами за [6]

За прогнозами топ-менеджменту банків, ризик ліквідності $(38,3 \%)$, валютний $(31,8 \%)$, кредитний $(30,2 \%)$ та процентний $(28,9 \%)$ ризики збільшаться у кінці 2018 року. При цьому операційний ризик не зміниться (98,7\% відповідей).

Ураховуючи зазначене, вважаємо, що фермер має обгрунтовано довести банкові переваги кредитування його бізнесу, а також надати всю вичерпну інформацію для більш точної оцінки кредитного ризику, щоб у топменеджерів не виникало ніяких сумнівів. Тільки за означених умов банк буде пропонувати сільгоспвиробникам оптимальні умови для співпраці.

Банк не працює в вакуумі, а залежить від багатьох зовнішніх чинників законодавчого середовища, загальних економічних тенденцій, поведінки контрагентів, інших факторів. Вартість фінансування в гривні залежить від вартості, за якою банки залучають кошти на міжбанківському ринку для подальшого кредитування аграрного сектора економіки. При зниженні вартості залучених ресурсів кредитні процентні ставки одночасно будуть знижуватися.

Отже, зблизити банк і аграрія може, у першу чергу, стабілізація в країні. Утім, до найбільших джерел ризику банки відносять сьогодні політичну і 
соціальну ситуацію в Україні (57\%), стан співпраці 3 міжнародними фінансовими організаціями (48\%), шахрайство та кібернетичні загрози і стан захисту прав кредиторів та інвесторів (48 і 35\% відповідно) (рис. 2).

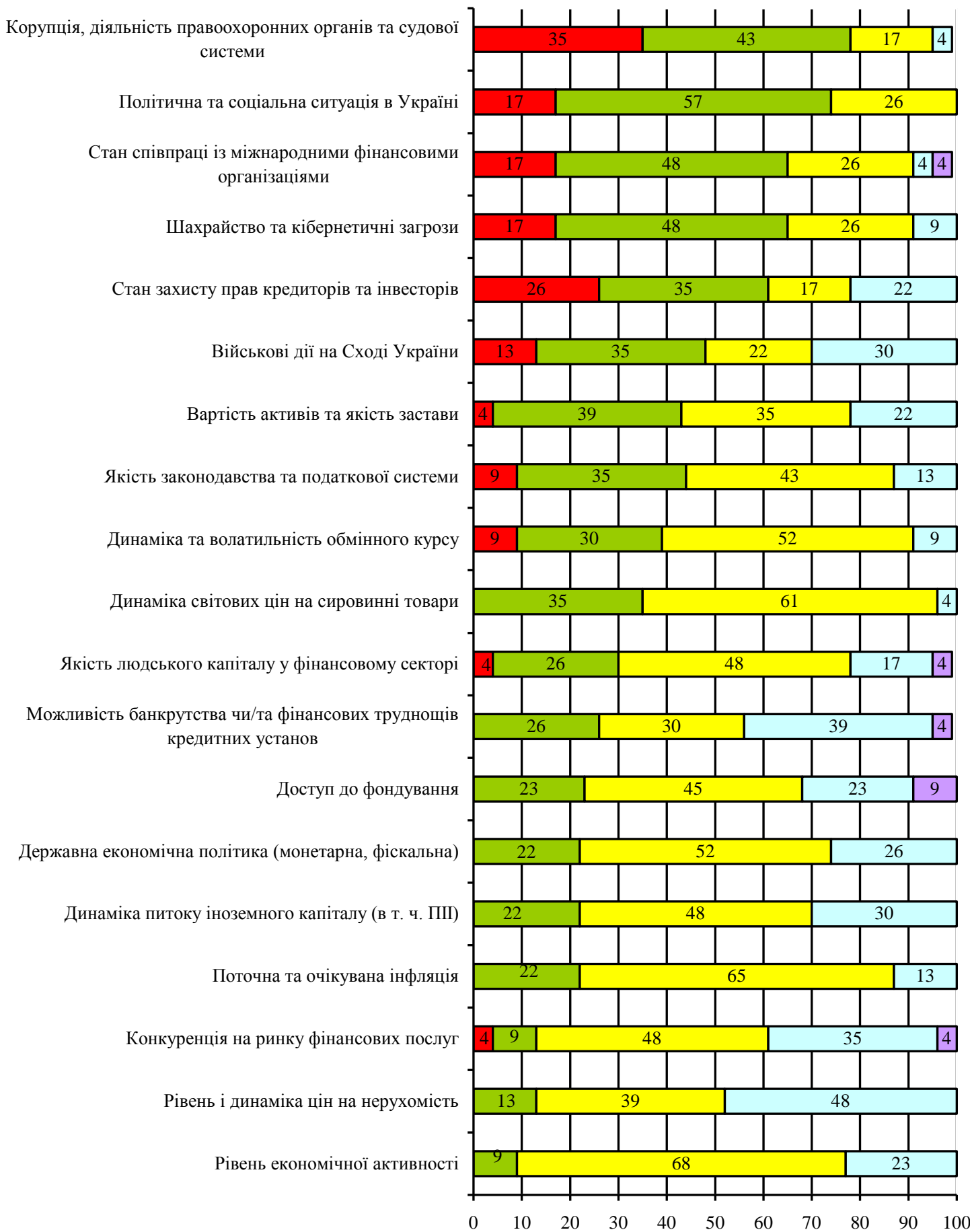

口Дуже високий, \% $\quad \square$ Високий, \% $\quad \square$ Середній, \% $\quad \square$ Низький, $\% \quad \square$ Дуже низький, \%

Рисунок 2 - Фактори впливу на рівень ризиків у банківському секторі у 2018 році, \% відповідей.

Джерело: складено авторами за [7].

Чим сприятливіше буде загальна ситуація в країні, тим доступніше і на більш тривалий термін банки будуть надавати кредити аграрному сектору. 
Банки для оцінювання ризиків кредитування агробізнесу використовують нові методики і різні інструменти, що дозволяє значно економити час і виконати оцінку максимально точно. Крім використання набору економічних індикаторів здійснюється комплексний аналіз і проводиться оцінка індикаторів виробничої діяльності агропідприємства за декілька років. У процесі аналізу порівнюється певний економічний індикатор даного сільгосппідприємства 3 відповідними індикаторами аналогічних сільгосппідприємств, що працюють на ринку. Ураховуючи, що фінансова звітність українських агропідприємств не завжди якісно підготовлена, менеджери використовують механізми внутрішньої перехресної перевірки даних. Використовується інноваційний підхід до побудови помісячних фінансових потоків на наступний рік на основі технологічних карт. Цей підхід дозволяє комплексно оцінити історичні дані і дати прогноз на майбутній період завдяки максимальній формалізації i автоматизації роботи 3 історичними даними.

Комерційні банки, які пропонують найкращі умови кредитування та підтримки агробізнесу представлено на рис. 3.

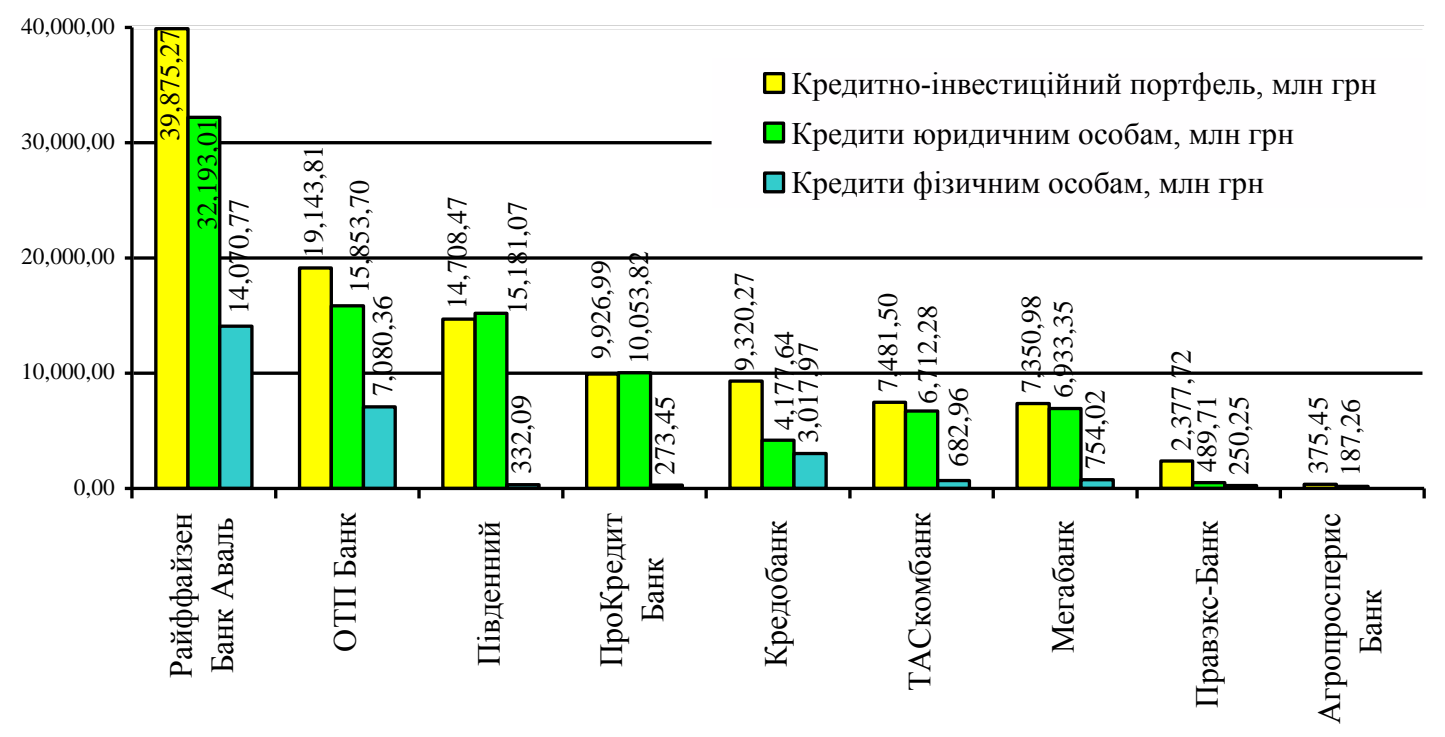

Рисунок 3 - Комерційні банки України, що активно працюють з аграрним сектором економіки, 2017 рік Джерело: складено авторами за [8]

Агропросперіс Банк кредитує тільки малих і середніх агровиробників, які мають від 100 га землі в обробці і вирощують основні експортні культури.

Відмітимо, що малі і середні підприємства АПК нині виступають головним локомотивом кредитування, оскільки якість кредитного портфеля в цьому сегменті значно вище, ніж, наприклад, якість кредитного портфеля корпоративних кліснтів. Тепер банки налаштовані на спрощення процесів щодо прийняття рішень про можливість кредитування малих i середніх підприємств АПК. Банки полегшують вимоги до аналізу управлінської звітності, скорочують терміни розгляду кредитних заявок. 
Однак топ-менеджери багатьох банків вважають, що кредитування великих агропідприємств $є$ більш вигідним бізнесом порівняно 3 фермерськими господарствами. Насправді складно 3 цією точкою зору погодитися, якщо згадати про ряд проблем, яких торкнулися відомі агрохолдинги і їх кредитори (дефолти «Креативу», «Агротону», «Мрії»).

Ураховуючи зазначене, відмітимо, що основним показником у діяльності аграрної компанії є не розмір земельного банку, яким вона керує, а якість (ефективність) управління таким банком. Не завжди величина компанії $\epsilon$ вирішальним фактором. Особлива роль у перевірці позичальника приділяється іміджу власника бізнесу, бо прислів'я: «Який агроном, такий і врожай» тут як ніколи вірне. Додатково вивчається стратегія і поведінка власника щодо землі. Детально з'ясовується структура витрат кожного господарства з розрахунку на гектар у зв'язку з одержуваною врожайністю культур. При цьому банк повинен системно підходити до визначення специфічних аграрних ризиків, належно оцінювати управлінські здібності менеджменту господарства i максимально точно окреслювати майбутні грошові потоки від різних видів виробництва, тоді відповідні ризики будуть покритими незалежно від величини підприємства.

Багатонадійні реклами банківських кредитних продуктів повсюди переконують аграріїв, що отримати фінансові ресурси в позику просто і життєво необхідно. Часто фермери швидко реагують на цей ринковий «фокус» доступності і, навіть, не задумуючись, що ситуація у будь-який момент може змінитися, беруть на себе тривалі боргові зобов'язання. Сільгоспвиробники, придбавши у кредит техніку або добрива i, не отримавши очікуваний урожай, у багатьох випадках не мають коштів на виплату відсотків по кредиту банку. Намагаючись самостійно домовитися з банком, вони лише натикаються на всілякі перешкоди. Не рідко після сумного досвіду спілкування з недбайливим банком, сільгоспвиробник відмовляється платити борг по кредиту.

Особливо це актуально в тих випадках, коли банк нараховує, приховані при укладанні договору, комісії або штрафи. Банки неохоче йдуть назустріч боржникам і вести переговори 3 ними вкрай важко. За оцінкою банків у II кварталі 2018 року боргове навантаження домогосподарств було на рівні середнього (59\% відповідей) (рис. 4).

Розподіл кредитів, наданих фізичним особам, за класами боржника (дефолтним або непрацюючим кредитом вважається 5 клас для фізичної особи) представлено в табл. 1. 


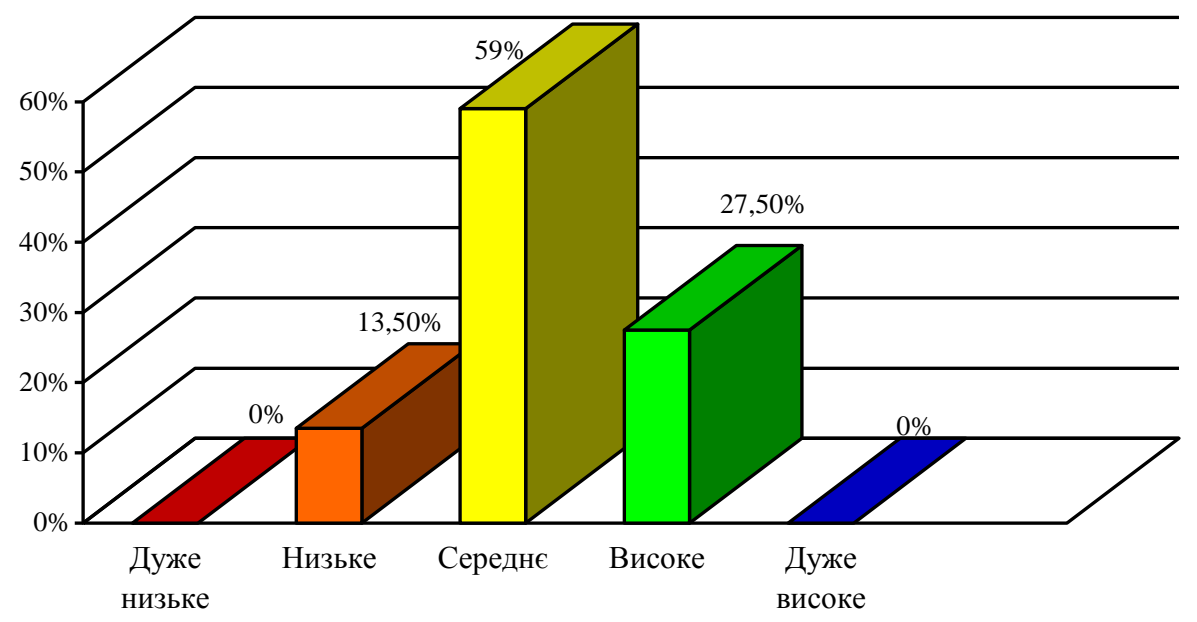

Рисунок 4 - Оцінка банками боргового навантаження у секторі домогосподарств у II кварталі 2018 року, \% відповідей Джерело: складено авторами за [6].

Відомо багато способів домовитися з банком, який зацікавлений в отриманні своїх грошей, а не у тривалих позовах 3 боржником: реструктуризація; рефінансування; індивідуальна консультація у юриста.

Таблиця 1 - Розподіл кредитів, наданих фізичним особам, за класами боржника станом на 01.09.2018 року, тис. грн.

\begin{tabular}{|l|l|c|c|c|c|c|}
\hline \multicolumn{1}{|c|}{ № } & \multicolumn{1}{|c|}{ Показник } & 1 & 2 & 3 & 4 & 5 \\
\hline 5 & АТ "УкрсоцБанк" & $1,304,824$ & 44,862 & 21,055 & 12,489 & $25,692,608$ \\
\hline 36 & АТ "Райффайзен Банк Аваль" & $4,965,236$ & 258,373 & 42,501 & 41,413 & $4,735,336$ \\
\hline 115 & ПАТ "ПУМБ" & $7,089,424$ & 102,529 & 92,579 & 48,952 & $2,948,944$ \\
\hline 136 & АТ "УкрСиббанк" & $3,867,650$ & 71,316 & 47,860 & 26,945 & $6,714,759$ \\
\hline 171 & ПАТ "Креді агріколь Банк" & $3,502,281$ & 64,028 & 32,471 & 29,249 & 210,188 \\
\hline 272 & АТ "Альфа-Банк" & $9,921,940$ & 187,798 & 117,037 & 73,818 & $3,597,786$ \\
\hline 296 & АТ "ОТП БАНК" & $4,892,045$ & 8,983 & 4,132 & 1,283 & $4,589,485$ \\
\hline 299 & АТ "Сбербанк" & 64,051 & 3,120 & 1,316 & 1,267 & $2,674,467$ \\
\hline
\end{tabular}

Джерело: складено авторами за [9]

У разі, якщо жоден з перерахованих вище методів не підходить, позичальник може не платити за кредит згідно з чинним законодавством. Нижче пропонується розглянути ці три документально підтверджених методи. Згідно з першим методом фізична особа розпочинає процедуру банкрутства. Якщо позичальник буде визнаний банкрутом відповідно до Закону України (ЗУ) «Про відновлення платоспроможності боржника або визнання його банкрутом», його активи реалізуються через торги на аукціоні і діляться між кредиторами, які заявили претензії [10]. Клієнт банку може залишитися боржником при звичайній процедурі вилучення застави, але при цьому суд звільняє його від додаткових виплат.

Другий метод - це визнання недійсним кредитного договору на підставі Цивільного Кодексу України, наприклад, при форс-мажорних обставинах (наприклад, девальвація гривні тощо) [11]. 
Третій - у випадку, якщо мова йде про валютний кредит, у силу вступають ст. 99 Конституції, ст. 35 3У «Про Національний банк України», згідно з якими гривня є єдиним законним засобом для виконання платіжних операцій на території України, тому всі позики в іноземній валюті можуть бути визнані недійсними [12].

Проте, за будь-яких обставин позичальник повинен зважено підходити до прийняття остаточного рішення про сплату чи не сплату по кредиту. Хоча багато фермерів добросовісно ставляться до боргів i не візьмуть на себе кредитні зобов’язання, якщо не спроможні їх віддати. Незалежно від ситуації, боржник свої дії мусить виконувати під пильним моніторингом практикованого юриста, інакше навіть незначні фінансові зобов'язання можуть привести до великих проблем.

Кредитування будь-якого підприємства i будь-якої галузі економіки пов'язано з ризиками, не виняток і малий агробізнес. Дійсно, аграрному сектору притаманні специфічні ризики i в цілому ця галузь $є$ більш ризикованою, ніж інші галузі економіки. Відмітимо, що обсяг прострочених боргів компаній аграрного сектора у 2017 році становив 5,9 млрд грн, або 12\% від загальної кількості виданих позик. Якщо брати до уваги кредитний портфель банку - це абсолютно допустимий показник. Для порівняння: у торгівлі рівень прострочення у цей період становив 15\%, у переробній галузі 46\%. При цьому велика частка проблемних кредитів доводиться на кредити в іноземній валюті (71\%). Обсяги непрацюючих кредитів представлено в табл. 2.

Таблиця 2 - Обсяги непрацюючих кредитів у 2018 році, млн. грн.

\begin{tabular}{|l|c|c|c|c|}
\hline Показник & 01.06 .2018 & 01.07 .2018 & 01.08 .2018 & 01.09 .2018 \\
\hline Кредити корпоративному сектору & 477,871 & 475,795 & 480,615 & 488,997 \\
\hline непрацюючі кредити & 275,363 & 274,450 & 271,483 & 272,569 \\
\hline частка непрацюючих кредитів, \% & 57,62 & 57,68 & 56,49 & 55,74 \\
\hline $\begin{array}{l}\text { Кредити фізичним особам (включно } \\
\text { із фізичними особами-підприємцями) }\end{array}$ & 120,442 & 121,830 & 125,708 & 130,568 \\
\hline непрацюючі кредити & 31,250 & 31,345 & 31,954 & 32,214 \\
\hline частка непрацюючих кредитів, \% & 25,95 & 25,73 & 25,42 & 24,67 \\
\hline $\begin{array}{l}\text { Міжбанківські кредити, депозити } \\
\text { (за виключенням коррахунків) }\end{array}$ & 2,607 & 3,436 & 2,830 & 3,746 \\
\hline непрацюючі кредити & 960 & 960 & 1,031 & 1,031 \\
\hline частка непрацюючих кредитів, \% & 36,81 & 27,95 & 36,44 & 27,52 \\
\hline $\begin{array}{l}\text { Кредити органам державної влади } \\
\text { та місцевого самоврядування }\end{array}$ & 998 & 1,627 & 1,834 & 2,091 \\
\hline непрацюючі кредити & 913 & 917 & 879 & 878 \\
\hline частка непрацюючих кредитів, \% & 91,49 & 56,38 & 47,94 & 41,98 \\
\hline
\end{tabular}

Зазначимо, що затримування розгляду питань 3 правом селян віддавати землю в заставу, зі складськими свідоцтвами не дозволяють банкам повною мірою використовувати ці ефективні засоби забезпечення кредитів $\mathrm{i}$, відповідно, гальмують розвиток кредитування підприємств АПК. Перепонами на шляху збільшення кредитування агросектору є відсутність досвіду роботи 
аграріїв у ринкових умовах господарювання, низька культура роботи позичальників з кредитами і відсутність необхідного досвіду позичальників про ринок кредитних послуг саме у сфері малого агробізнесу. Доречно вказати також на високу залежність платоспроможності позичальників від таких форсмажорних факторів, як погодні умови, зношеність основних фондів, не диверсифікований бізнес, а також відсутність довгострокових кредитів для сільгоспвиробників. Річ у тім, що потреба сільгоспвиробників у довгострокових кредитах задовольняється нині лише на 2\%, у той час як за короткостроковими кредитами - на 50\%. Вважаємо це серйозною проблемою для розвитку фермерства в Україні, оскільки в даному випадку аграрії змушені спрямовувати обігові кошти на придбання довгострокових активів. Час від часу неминучою $є$ практика продажу фермерами основних засобів для покриття поточних витрат.

Іноді банкіри нарікають на те, що аграрії-позичальники надають їм недостатньо інформації для прийняття зважених рішень про кредитування. Банки розраховують на більшу транспарентність бізнесу, зокрема висувають підвищені вимоги до фінансової звітності. Проблема полягає в тому, що не завжди можна чітко ідентифікувати кінцевого бенефіціара підприємства, а банкіри повинні володіти інформацією про особу, що отримує прибуток від своєї власності. Якщо розглядати фінансовий стан клієнта, то часто позичальник не може надати якісну консолідовану фінансову звітність за високими стандартами. Його бізнес малодохідний, у нього заборгованість перед бюджетом або перед іншими установами, і при цьому він приходить за кредитом. У зв'язку з цим банки стають більш вимогливими до потенційних позичальників (тепер клієнти повинні надавати не тільки якісні застави під кредити, але і вести прозору діяльність).

Висновки. Встановлені фактори впливу від найбілыш важливого до найменш значимого на прийняття рішення про кредитування сільгоспвиробника i вказано орієнтовний процент значущості кожного, виходячи 3 банківської практики: достовірність наданих даних про себе, власне господарство, плани по використанню отриманих фінансових ресурсів - 25\%; діловий імідж і кредитна історія сільгоспвиробника і його господарства - 20\%; досвід роботи фермера в агробізнесі - 20\%; фінансовий стан позичальника та його господарства - 15\%; рівень використовуваних в агробізнесі нововведень - 15\%; запропоноване заставне забезпечення по кредиту - 5\%. Можливості отримати кредит будуть максимальні, якщо фермер переконає банк у тому, що його сумніви про можливе неповернення коштів безгрунтовні.

Виявлено проблеми 3 боку позичальника, що стають основними перепонами до отримання позики: негативний імідж господарства або сумнівна кредитна історія; розбіжності в інформації, що надається банку в тому числі у фінансових документах; малий досвід у веденні агробізнесу; відсутність розуміння джерел фінансування господарства на майбутній період i шляхів повернення коштів кредиторам; невідповідність планів 
сільгоспвиробника і реальних можливостей господарства; закредитованість господарства; недостатній пріоритет питання щодо отримання позики для власних співробітників.

Сформульовані ключові елементи одного 3 найголовніших етапів у процесі видачі кредиту - фінансово-аграрної експертизи, яку проводять співробітники банку після отримання заявки на його видачу: наявність у фермера чіткого і реального фінансового плану (в якому будуть розписані витрати, джерела фінансування, прогноз виручки i терміни повернення коштів); інформація щодо агротехнологій, які використовуються в господарстві; дані щодо кваліфікації співробітників господарства; дані про наявність достатньої кількості техніки для певного обсягу робіт або план по іiі залученню зі сторони; статус землі (наприклад, терміни іiі оренди); дані про кредитну історію, наявності суперечок, судів. Пропозиції фермерам: щоб не було проблем - не треба приховувати інформацію в тих питаннях, які будуть перевіряти банківські працівники.

Перспективи подальших наукових розробок пов'язані нагальною необхідністю наукового аналізу і узагальнення кращого міжнародного досвіду в сфері фінансування агарного сектора економіки.

Результати наукового пошуку можуть бути використані законодавчими i виконавчими органами влади та місцевого самоврядування при розробці відповідних документів 3 метою розвитку i підвищення ефективності функціонування підприємств АПК.

\section{Література:}

1. Дем'яненко М.Я., Саблук П.Т., Скупий В.М. Державна політика фінансової підтримки розвитку аграрного сектору АПК: монографія. Київ: ННЦ IAE, 2011. 372 с.

2. Корнійчук Г.В. Фінансові ресурси як елемент фінансового потенціалу агроформувань. Інвестииії: практика та досвід. 2017. № 8. С. 44-45.

3. Лупенко Ю.О., Фещенко В.В. Сучасні інструменти для фінансування аграрного сектору економіки. Фінансовий ринок Украӥни. 2012. № 12. С. 26-30.

4. Непочатенко О.О., Бечко П.К., Корнега А.О. Кредитні ризики в системі банківського кредитування аграріїв. Збірник наукових праџь Уманського наџіонального університету садівниитва. 2016. № 88 (2). С. 7-20.

5. Халатур С.М., Гармаш М.С. Фінансово-кредитне забезпечення сільськогосподарської галузі на основі оптимізації банківських активів. Економіка та держава. 2017. № 9. С. 78-81.

6. Опитування про умови банківського кредитування. Національний банк України. 2018. URL: https://bank.gov.ua/doccatalog/document?id=74308529 (дата звернення: 11.09.2018).

7. Опитування про системні ризики фінансового сектору Національний банк України. 2018. URL: https://bank.gov.ua/doccatalog/document?id=70786785 (дата звернення: 12.09.2018).

8. ТОП-8 аграрных банков 2017. 27.12.2017. URL. https://latifundist.com/rating/top-8agrarnyh-bankov-2017 (дата звернення: 10.10.2018).

9. Показники банківської системи. Наџіональний банк України. 2018. URL: https://bank.gov.ua/control/uk/publish/article?art_id=34661442\&cat_id=34798593 (дата звернення: 15.09.2018).

10. Про відновлення платоспроможності боржника або визнання його банкрутом: Закон України від 14.05.1992 р. № 31. Відомості Верховної Ради України. Дата оновлення: 13.03.2018. № 16. URL: http://zakon.rada.gov.ua/laws/show/2343-12 (дата звернення: 05.10.2018). 
11. Цивільний Кодекс України: Закон України від 16.01.2003 p. № 435-IV. Відомості Верховної Ради України. Дата оновлення: 02.08 .2018 p. № 2505-VIII. URL: http://zakon.rada.gov.ua/laws/show/435-15 (дата звернення: 17.10.2018).

12. Про Національний банк України: Закон України від 17.02.1999 р. № 29. Вiдомості Верховної Ради Украӥни. Дата оновлення: 06.02.2018 p. № 11. URL: http://zakon.rada.gov.ua/laws/show/679-14 (дата звернення: 15.09.2018).

УДК 338.2:631.152.3

JEL classification $O 11 ; O$ 13; D 24; $Q 18$

Romanii Y.

ORCID ID: 0000-0002-8949-9885

National Technical University of Ukraine «Igor Sikorsky Kyiv Polytechnic Institute»

\title{
THE FORMATION OF STRATEGIC MANAGEMENT MODEL WITH RESOURCE POTENTIAL FOR ENTERPRISES IN AGRICULTURAL FIELD
}

\author{
ФОРМУВАННЯ МОДЕЛІ СТРАТЕГІЧНОГО УПРАВЛІННЯ РЕСУРСНИМ \\ ПОТЕНЦАЛОМ ПІДПРИСМСТВ АГРАРНОЇ ГАЛУЗІ
}

In the article was improved the importance of strategic management of resource potential of enterprises in agricultural fields. Was analyzed the current process of strategic management at domestic enterprises, found main problems and disadvantages. The approaches of scientists to definition of concepts "strategic management" and reasons of variability of approaches were considered and offered the author's definition of the concept from the point of view as its practical application in enterprises activity. Were also proposed definitionsof "resource potential" and "strategic management of resource potential"concepts.Wasdetermined the peculiarities of activity of agrarian enterprises, which should be taken into account in the process of strategic management. The strategic management model with resource potential of agricultural enterprises was formed and its based on six stages: mission formation, short-term and long-term goals formation; analysis and evaluation of the current status of the resource potential of the enterprise, SWOT analysis, search for opportunities for attracting resources and assessment of alternatives to their combination; the formation of the resource strategy of the enterprise, the outline of the final objectives of its implementation, reflected in specific indicators, analysis of their compliance with the general objectives of the enterprise, the formation of strategic plans (chart of resource attraction depending on production program, plan of existence and necessity of resources' search, optimization directions of resources' attraction, allocation and usage, etc.); implementation of the chosen strategy and control over the indicators, interim and final analyzes of the deviation plan / fact, identifying the causes and adjusting the resource strategy and plans.Also, the article highlights the main factors of effective strategic management of resource potential in the modern competitive environment, implementation of which will allow enterprises of agricultural fields to increase their competitive advantages both in domestic and in foreign markets.

Keywords: potential, strategy, management, resources, production, agricultural field

У статті доведено важливість стратегічного управління ресурсним потенціалом підприємств аграрної галузі. Проаналізовано поточний прочес стратегічного управління на вітчизняних підприємствах, окреслено основні його проблеми та недоліки. Розглянуто 